Harliwanti Prisilia \& Dimas Aji Purnomo : Aplikasi Metode Lean Project Management Dalam Perencanaan Proyek Konstruksi Pada Pembangunan Gedung SMU Negeri 1 Giri Kabupaten Banyuwangi

\title{
APLIKASI METODE LEAN PROJECT MANAGEMENT DALAM PERENCANAAN PROYEK KONSTRUKSI PADA PEMBANGUNAN GEDUNG SMU NEGERI 1 GIRI KABUPATEN BANYUWANGI
}

\author{
Harliwanti Prisilia ${ }^{1}$; Dimas Aji Purnomo ${ }^{1}$ \\ (1) Teknik Industri, Fakultas Teknik, Universitas 17 Agustus 1945 Banyuwangi \\ Email: harliwantip@gmail.com
}

\begin{abstract}
Abstrak:
Kurangnya perencanaan yang baik merupakan faktor yang berpengaruh pada terlambatnya proses konstruksi. Untuk mengatasi hal tersebut, dapat digunakan pendekatan konsep lean dalam perencanaan proyek yang bertujuan untuk meminimalisir waste dan mengidentifikasi resiko yang ada pada proyek pembangunan. Permasalahan dan tujuan yang di fokuskan dalam penelitian ini adalah bagaimana mengidentifikasi dan mengurangi waste serta identifikasi resiko berdasarkan waste pada proyek konstruksi pembangunan gedung SMUN 1 Giri Banyuwangi dengan menggunakan konsep lean. Hasil identifikasi menunjukkan bahwa waste yang berpengaruh dan berpotensi pada proyek yang digunakan adalah waiting dan difect. Waste waiting di sebabkan karena faktor keterlambatan material, keterlambatan penurunan dana, cuaca buruk dan alat/ mesin yang sering rusak. Sedangkan waste difect disebabkan karena cuaca buruk dan alat/mesin yang sering rusak. Hasil penjadawalan dengan Critical Chain Project Management (CCPM) didapatkan waktu mengerjakan proyek adalah 131 hari dimana lebih cepat 29 hari dibandingkan dengan menggunakan penjadwalan eksisting selama 160 hari.
\end{abstract}

Kata kunci : Lean, Critical Chain Project Management, Waste, Konstruksi

\begin{abstract}
:
Lack of good planning is a factor that affects the late construction process. To overcome this, a lean concept approach can be used in project planning that aims to minimize waste and identify the risks involved in development projects. The problems and objectives that focus on this research are how to identify and reduce waste and identification of risk based on waste in construction project of SMUN 1 Giri Banyuwangi building by using lean concept. The results of identification indicate that the waste that is influential and potential in the project used is waiting and difect. Waste waiting is caused by material delay factors, delays in funding declines, bad weather and equipment / machines are often damaged. While waste difect caused by bad weather and tools / machines are often damaged. The result of the scheduling with Critical Chain Project Management (CCPM) got the time to work on the project is 131 days which is faster 29 days compared to using the existing scheduling for 160 days.
\end{abstract}

Keyword : Lean, Critical Chain Project Management, Waste, Costruction 

Harliwanti Prisilia \& Dimas Aji Purnomo : Aplikasi Metode Lean Project Management Dalam Perencanaan Proyek Konstruksi Pada Pembangunan Gedung SMU Negeri 1 Giri Kabupaten Banyuwangi

\section{PENDAHULUAN}

Kendala maupun kegagalan konstruksi sering terjadi saat pelaksanaan proyek konstruksi. Kegagalan atau masalah yang sering terjadi di proyek adalah sering terjadinya ketidaksesuaian antara rencana awal dengan realisasi yang ada dalam pelaksanaan proyek (Anggraeni, 2009). Walaupun kegagalan tidak dapat dilihat secara langsung, tetapi jika berlangsung dengan terus menerus dan intensitas yang sering maka akan terakumulasi pada akhir proyek misalnya dalam bentuk keterlambatan pelaksanaan proyek dari jadwal yang sudah ditentukan maupun kenaikan anggaran biaya dari awal yang sudah direncanakan (Ismael, 2014) . Hal tersebut dinamakan dengan waste (pemborosan).

Istilah waste juga disebut dengan non value adding activities disebabkan oleh tidak efektifnya faktor-faktor yang terlibat dalam pelaksanaan proyek (man,method, material, machine, environment), sehingga dapat menimbulkan keterlambatan dalam penyelesaian proyek (Gray, 2006). Untuk mengatasi kedala-kendala tersebut diperlukan suatu pendekatan lean thinking atau dalam manajemen proyek dikenal dengan nama Lean Project Management ( LPM ) yang di dalamnya terdapat prinsip-prinsip yang dapat diaplikasikan untuk pelaksanaan proyek konstruksi. Lean Project Management merupakan metode kerja yang fokus terhadap proses. Menurut Leach (2005) metode Lean Project Management ini menggabungkan metode Critical Chain Project Management (CCPM) untuk penjadwalan dan lean tools untuk identifikasi waste dan penyebabnya sehingga tidak terjadi keterlambatan dan pembengkakan biaya dalam pelaksanaan proyek.

Namun demikian, masih ada beberapa badan usaha di bidang jasa konstruksi, yang masih melakukan pekerjaan proyek dengan metodemetode tradisional tanpa melakukan pengaplikasian metode yang terstruktur. Salah satunya adalah PT. Rajek Wesi, Banyuwangi yang merupakan pelaksana pada proyek pembangunan gedung SMU Negeri 1 Giri, Banyuwangi. Untuk itu perlu dilakukan proses perbaikan dalam perencanaan, sebelum dimulainya proyek konstruksi tersebut dengan mengaplikasikan metode Lean Project Management. Pendekatan Lean Project Management (LPM) dalam perencanaan pembangunan gedung SMU Negeri 1 Giri ini mempunyai tujuan untuk mengidentifikasi waste, resiko dan estimasi kebutuhan proyek dari segi waktu, sumber daya, biaya. Untuk estimasi waktu dilakukan dengan menggunakan metode Critical Chain Project Management yang digunakan sebagai dasar rekomendasi penjadwalan proyek.

\section{METODE}

Metode yang di gunakan dalam penelitian dengan cara mengumpulkan data primer dan data sekunder. Obyek pada penelitian ini adalah proyek pembangunan SMUN 1 Giri Banyuwangi. Tahapan yang dilalukan dalam penelitian ini meliputi :

a. Pemetaan Aktvitas Kerja

Pemetaan aktivitas kerja yang dilakukan pada tahap ini adalah melalui pengelompokan aktivitasaktivitas proyek dengan menggunakan Work Breakdown Sructure (WBS). Dalam

WBS dilakukan breakdown aktivitas dari proyek secara utuh hingga ke subderivabel paling rendah.

b. Identifikasi Waste

Setelah diketahui aktivitas proyek selanjutnya dilakukan identifikasi waste yang terdapat pada proyek dengan melakukan wawancara pada pihak pelaksana proyek. Berdasarkan hasil wawancara diketahui bahwa waste yang terjadi pada proyek adalah waste waiting dan defect.

c. Root Cause Analysis (RCA) 
Harliwanti Prisilia \& Dimas Aji Purnomo : Aplikasi Metode Lean Project Management Dalam Perencanaan Proyek Konstruksi Pada Pembangunan Gedung SMU Negeri 1 Giri Kabupaten Banyuwangi

Setelah waste diketahui, tahap selanjutnya adalah mengidentifikasi faktor-faktor penyebab

terjadinya waste dengan menggunakan metode RCA. Langkah selanjutnya setelah faktor

penyebab waste diketahui diolah dalam formulasi if then agar dapat diketahui tindakanatau

solusi yang dapat ditempuh untuk meminimalisir terjadinya waste. Untuk faktor yang memiliki lebih dari satu solusi dilakukan matriks evaluasi yang pada akhirnya akan dihasilkan rekomendasi untuk meminimalisir atau menghilangkan waste.

d. Identifikasi Resiko

Proses identifikasi risiko dilakukan dengan cara teknik survey, brainstorming dengan expert, literatur review. Faktorfaktor yang diidentifikasi menyangkut faktor ekternal maupun faktor internal untuk mengetahui sumber-sumber resiko dan indikatornya. Adapun wawancara dan brainstorming dilakukan dengan pihak pelaksana proyek.

e. Risk Priority Number (RPN)

Setelah sumber resiko dan indikatornya diketahui, dilakukan langkah perhitungan RPN untuk penilaian resiko dengan pelakukan pengisian form penilaian resiko dengan menggunakan metode Failure Mode and Effect Analysis (FMEA). Jika peristiwa resiko telah dikenali dan di beri nilai maka langkah berikutnya adalah membuat keputusan untuk merespon dengan tepat peristiwa tersebut dengan membuat matriks respon resiko berikut analisa resikonya.

f. Managing Variation (Pengelolaan variasi)
Variasi didalam proyek diartikan ketidakpastian, untuk itu pihak pelaksana perlu memanage variasi, dengan cara mengestimasi sebelum pelaksanaan proyek baik dari segi biaya, waktu, dan sumber daya yang digunakan.Tujuan mengestimasi adalah agar manajemen proyek dapat meramalkan atau memperkirakan waktu, biaya dan sumber dayayang dibutuhkan saat pelaksanaan proyek.

g. Penjadwalan CCPM

Critical Chain Project

Manajement (CCPM) digunakan untuk penjadwalan proyek, dengan melihat penjadwalan eksisting proyek perusahaan. Kemudian menentukan critical chain, dan pemotongan safety time pada tiap-tiap aktivitas proyek dari pengurangan antar durasi yang memiliki safety di tiap aktivitasnya. (Santosa, 2013). Selanjutnya yaitu menentukan ukuran buffer melalui pemotongan baffer yang dihasilkan dari pemotongan safety time. Tahap selanjutnya yaitu penentuan letak buffer, yang berupa fedding buffer dan project buffer sebagai cara untuk melindungi target waktu penyelesaian. Tahap terakhir yaitu membandingkan antar penjadwalan existing dengan penjadwalan yang menggunakan Critical chain.

h. Kesimpulan

Setelah melakukan perhitungan RPN dengan metode FMEA,selanjutnya dilakukan penarikan kesimpulan. Penarikan kesimpulan adalah jawaban dari tujuan penelitian, yang pada akhirnya dapat diberikan saran dan masukan terkait waste dan resiko yang terjadi pada proyek pembangunan.

\section{HASIL DAN PEMBAHASAN}


Harliwanti Prisilia \& Dimas Aji Purnomo : Aplikasi Metode Lean Project Management Dalam Perencanaan Proyek Konstruksi Pada Pembangunan Gedung SMU Negeri 1 Giri Kabupaten Banyuwangi

a. Identifikasi dan Analisa Waste Identifikasi waste yang ada pada penelitian ini adalah 8 macam waste menurut Womack dan Jones (1996).
Dari 8 waste yang telah diidentifikasi berikut ini adalah perbandingan bentukbentuk waste proses manufaktur dan proyek konstuksi (Hapsari, 2011).

Tabel 1. Perbandingan Bentuk 8 Waste Dalam Manufaktur Dan Konstruksi

\begin{tabular}{|c|c|c|}
\hline Waste & Manufaktur & Proyek konstruksi \\
\hline Defect & $\begin{array}{l}\text { Terjadinya cacat atau } \\
\text { penurunan kualitas output }\end{array}$ & $\begin{array}{l}\text { Material yang masih di } \\
\text { butuhkan mengalami kerusakan } \\
\text { akibat kesalahan proses } \\
\text { pemasangan, pembuatan atau } \\
\text { penyimpanan. }\end{array}$ \\
\hline Overproduction & $\begin{array}{l}\text { Produksi berlebihan } \\
\text { dibandingkan demand }\end{array}$ & Repair atau rework bangunan \\
\hline \multirow[t]{4}{*}{ Waiting } & \multirow{4}{*}{$\begin{array}{l}\text { Adanya personel atau } \\
\text { material yang tidak aktif } \\
\text { dslam waktu yang lama. }\end{array}$} & $\begin{array}{l}\text { Menunggu material, peralatan, } \\
\text { dan pekerja datang }\end{array}$ \\
\hline & & $\begin{array}{lll}\text { Menunggu peralatan yang } \\
\text { diperbaiki }\end{array}$ \\
\hline & & $\begin{array}{l}\text { Cuaca tidak mendukung untuk } \\
\text { melakukan aktifitas }\end{array}$ \\
\hline & & $\begin{array}{ll}\text { Menunggu interuksi } & \text { dari } \\
\text { pimpinan lapangan }\end{array}$ \\
\hline $\begin{array}{l}\text { Unappropriate } \\
\text { procesing }\end{array}$ & $\begin{array}{l}\text { Peralatan atau mesin yang } \\
\text { tidak sesuai }\end{array}$ & $\begin{array}{l}\text { Peralatan atau prosedur } \\
\text { pekerjaan yang tidak sesuai } \\
\text { dengan standar yang telah } \\
\text { ditetapkan }\end{array}$ \\
\hline Unnecessary motion & $\begin{array}{l}\text { Adanya gerakan yang } \\
\text { tidak perlu }\end{array}$ & $\begin{array}{l}\text { Pergerakan pekerja yang tidak } \\
\text { produktif (berpindah, mencari, } \\
\text { dan berjalan) }\end{array}$ \\
\hline $\begin{array}{l}\text { Excessive } \\
\text { transportation }\end{array}$ & $\begin{array}{lr}\text { Adanya } & \text { perpindahan } \\
\text { transportasi } & \text { yang } \\
\text { berlebihan } & \end{array}$ & $\begin{array}{l}\text { Perpindahan aliran fisik } \\
\text { material yang terlalu berlebihan }\end{array}$ \\
\hline Unnecessary inventory & $\begin{array}{l}\text { Efek dari overproduction } \\
\text { yang menyebabkan } \\
\text { meningkatnya inventory } \\
\text { finished good dan sisa } \\
\text { material yang berlebih }\end{array}$ & $\begin{array}{l}\text { Menyediakan material yang } \\
\text { lebih dari kebutuhan }\end{array}$ \\
\hline $\begin{array}{l}\text { Design barang atau jasa } \\
\text { yang tidak memuaskan }\end{array}$ & $\begin{array}{l}\text { Design barang yang tidak } \\
\text { sesuai dengan design awal } \\
\text { produk }\end{array}$ & $\begin{array}{l}\text { Design bangunan } \\
\text { sesuai dengan tidak } \\
\text { pelanggan }\end{array}$ \\
\hline
\end{tabular}

Identifikasi waste diolah dengan menggunakan metode Root Cause Analysis (RCA) (Untu, 2104). Identifikasi waste berdasarkan waste yang paling berpengaruh dan berpotensi terjadi pada proyek. Berdasarkan hasil wawancara dengan PT. Rajek Wesi sebagai pelaksana proyek dan juga dengan hasil observasi di lapangan, waste yang paling berpotensi muncul pada proyek yang di teliti adalah waiting dan defects. 
Harliwanti Prisilia \& Dimas Aji Purnomo : Aplikasi Metode Lean Project Management

Dalam Perencanaan Proyek Konstruksi Pada Pembangunan Gedung SMU

Negeri 1 Giri Kabupaten Banyuwangi berikut:

Adapun faktor-faktor penyebab waiting pada proyek ini dapat dilihat pada gambar

\begin{tabular}{|c|c|c|c|c|c|c|}
\hline \multicolumn{7}{|c|}{ Tabel 2. RCA } \\
\hline Waste & Sub waste & Why 1 & Why 2 & Why 3 & Why 4 & Why 5 \\
\hline \multirow{5}{*}{ Waiting } & \multirow{2}{*}{$\begin{array}{l}\text { Menunggu } \\
\text { Material } \\
\text { datang }\end{array}$} & \multirow{2}{*}{$\begin{array}{c}\text { Keterlambat } \\
\text { an } \\
\text { pengiriman } \\
\text { material/ } \\
\text { mesin }\end{array}$} & \multirow{2}{*}{$\begin{array}{c}\text { Tidak } \\
\text { tepatnya } \\
\text { jadwal } \\
\text { pengiriman } \\
\text { material }\end{array}$} & \multirow{2}{*}{$\begin{array}{c}\text { Kurangnya } \\
\text { koordinasi/ } \\
\text { komunikasi } \\
\text { dengan } \\
\text { penyedia } \\
\text { material }\end{array}$} & $\begin{array}{c}\text { Ketidak } \\
\text { tepatan } \\
\text { dalam } \\
\text { pemesanan } \\
\text { material } \\
\end{array}$ & \\
\hline & & & & & $\begin{array}{c}\text { Adanya } \\
\text { perubahan } \\
\text { material }\end{array}$ & $\begin{array}{c}\text { Material } \\
\text { tidak sesuai } \\
\text { dengan } \\
\text { pemesanan }\end{array}$ \\
\hline & $\begin{array}{l}\text { Menunggu } \\
\text { turunnya } \\
\text { dana proyek }\end{array}$ & $\begin{array}{c}\text { Keterlambat } \\
\text { an } \\
\text { penurunan } \\
\text { dana proyek }\end{array}$ & $\begin{array}{l}\text { Pengajuan } \\
\text { dana belum } \\
\text { di setujui }\end{array}$ & $\begin{array}{c}\text { Kurangnya } \\
\text { koordinasi/ } \\
\text { komunikasi } \\
\text { dengan } \\
\text { pihak } \\
\text { penyandang } \\
\text { dana }\end{array}$ & & \\
\hline & $\begin{array}{l}\text { Menunggu } \\
\text { cuaca } \\
\text { normal }\end{array}$ & $\begin{array}{c}\text { Cuaca yang } \\
\text { tidak } \\
\text { mendukung } \\
\text { (Cuaca } \\
\text { buruk) }\end{array}$ & & & & \\
\hline & $\begin{array}{l}\text { Menunggu } \\
\text { alat/mesin } \\
\text { di perbaiki }\end{array}$ & $\begin{array}{c}\text { Kurangnya } \\
\text { pemelihara- } \\
\text { an terhadap } \\
\text { alat/mesin }\end{array}$ & $\begin{array}{c}\text { Tidak } \\
\text { adanya } \\
\text { jadwal yang } \\
\text { teratur dalam } \\
\text { pemelihara- } \\
\text { an alat/ } \\
\text { mesin }\end{array}$ & & & \\
\hline Waste & Sub waste & Why 1 & Why 2 & Why 3 & Why 4 & Why 5 \\
\hline & & Cuaca buruk & & & & \\
\hline & $\begin{array}{c}\text { Kualitas } \\
\text { hasil } \\
\text { bangunan } \\
\text { kurang baik }\end{array}$ & $\begin{array}{l}\text { Alat/mesin } \\
\text { rusak }\end{array}$ & $\begin{array}{l}\text { Kurangnya } \\
\text { pemelihara- } \\
\text { an terhadap } \\
\text { alat/mesin }\end{array}$ & $\begin{array}{c}\text { Tidak } \\
\text { adanya } \\
\text { jadwal yang } \\
\text { teratur dalam } \\
\text { pemelihara- } \\
\text { an alat/ } \\
\text { mesin }\end{array}$ & & \\
\hline
\end{tabular}

Defect

Kesalahan

\begin{tabular}{|c|c|c|}
\hline $\begin{array}{c}\text { Kualitas } \\
\text { material } \\
\text { yang tidak } \\
\text { sesuai }\end{array}$ & $\begin{array}{l}\text { proses dalam } \\
\text { pemasa- } \\
\text { ngan, } \\
\text { pembuatan/p } \\
\text { enyimpan-an }\end{array}$ & $\begin{array}{l}\text { Kurangnya } \\
\text { pengawa- } \\
\text { san }\end{array}$ \\
\hline
\end{tabular}


Harliwanti Prisilia \& Dimas Aji Purnomo : Aplikasi Metode Lean Project Management Dalam Perencanaan Proyek Konstruksi Pada Pembangunan Gedung SMU Negeri 1 Giri Kabupaten Banyuwangi

Dari penyebab muculnya waste tersebut kemudian di olah dalam formulasi if then untuk mengetahui tindakn-tindakan yang dapat di tempuh untuk meminimalisir atau menghilangkan waste, yang dapat dilihat pada tabel berikut ini:

Tabel 3. Identifikasi waste dengan formulasi if then

\begin{tabular}{|c|c|c|}
\hline \multicolumn{3}{|c|}{ CONTROLING WASTE } \\
\hline If & Then & When \\
\hline \multirow{2}{*}{$\begin{array}{c}\text { Keterlambatan } \\
\text { Datangnya } \\
\text { Material }\end{array}$} & \multirow{2}{*}{$\begin{array}{c}\text { Melakuakan pekerjaan lainnya yang tidak menggunakan } \\
\text { material yang datang terlambat }\end{array}$} & $\begin{array}{c}\text { Saat } \\
\text { Pelaksanaan }\end{array}$ \\
\hline & & $\begin{array}{c}\text { Saat } \\
\text { Pelaksanaan }\end{array}$ \\
\hline \multirow{2}{*}{$\begin{array}{l}\text { Keterlambatan } \\
\text { penurunan } \\
\text { dana }\end{array}$} & \multirow{2}{*}{ Menggunakan dana talangan } & $\begin{array}{c}\text { Saat } \\
\text { Pelaksanaan }\end{array}$ \\
\hline & & $\begin{array}{c}\text { Saat } \\
\text { Pelaksanaan }\end{array}$ \\
\hline \multirow{2}{*}{ Cuaca buruk } & Mengajukan surat keterlambatan pengerjaan & $\begin{array}{c}\text { Saat } \\
\text { Pelaksanaan }\end{array}$ \\
\hline & Melakukan percepatan pekerjaan saat cuaca kembali normal & $\begin{array}{c}\text { Saat } \\
\text { Pelaksanaan }\end{array}$ \\
\hline \multirow{2}{*}{$\begin{array}{l}\text { Alat sering } \\
\text { rusak }\end{array}$} & Melakukan perbaikan dan perawatan alat secara teratur & $\begin{array}{c}\text { Saat } \\
\text { Pelaksanaan } \\
\end{array}$ \\
\hline & Membeli alat yang baru & $\begin{array}{c}\text { Saat } \\
\text { Pelaksanaan }\end{array}$ \\
\hline
\end{tabular}

Dari tabel diatas di hasilkan solusi tindakan untuk penyebab terjadinya waste. Untuk penyebab yang memiliki lebih dari satu solusi dan di implomentasikan pada saat yang sama di olah dalam matriks evaluasi untuk mendapatkan solusi terbaik.

\section{b. Matriks Evaluasi}

Matriks evaluasi bertujuan untuk mengetahui solusi mana yang untuk dipilih berdasarkan beberapa kriteria dengan melakukan pembobotan oleh pihak pelaksana proyek.dari pembobotan tersebut di dapatkan skoring tioap-tiap solusi sehingga dapat di putuskan solusi mana yang "GO" atau "NOT GO" pada tabel di bawah ini dapat dilihat matriks evaluassinya: 
Tabel 4. Matriks Evaluasi Cuaca Buruk

\begin{tabular}{|c|c|c|c|c|c|}
\hline \multirow{3}{*}{ Kriteria } & \multirow{3}{*}{$\begin{array}{l}\text { Weight } \\
\text { factor }\end{array}$} & \multicolumn{4}{|c|}{ Cuaca Buruk } \\
\hline & & \multicolumn{2}{|c|}{$\begin{array}{c}\text { Mengajukan surat pengajuan } \\
\text { keterlambatan pekerjaan }\end{array}$} & \multicolumn{2}{|c|}{$\begin{array}{l}\text { Melakukan percepatan pekerjaan } \\
\text { saat kondisi cuaca kembali normal }\end{array}$} \\
\hline & & Ranking & Weighted score & Ranking & Weighted score \\
\hline Biaya & 8 & 9 & 72 & 3 & 24 \\
\hline Waktu & 8 & 6 & 48 & 4 & 32 \\
\hline $\begin{array}{l}\text { Dampak } \\
\text { terhadap } \\
\text { hasil }\end{array}$ & 7 & 8 & 56 & 5 & 35 \\
\hline Resiko & 6 & 7 & 42 & 5 & 30 \\
\hline \multicolumn{2}{|c|}{ Total } & \multicolumn{3}{|c|}{218} & 12 \\
\hline \multicolumn{2}{|c|}{ GO/NOT GO } & \multicolumn{2}{|r|}{ GO } & \multicolumn{2}{|c|}{ NOT GO (GO II) } \\
\hline
\end{tabular}

Tabel 5. Matriks Evaluasi Alat / Mesin Rusak

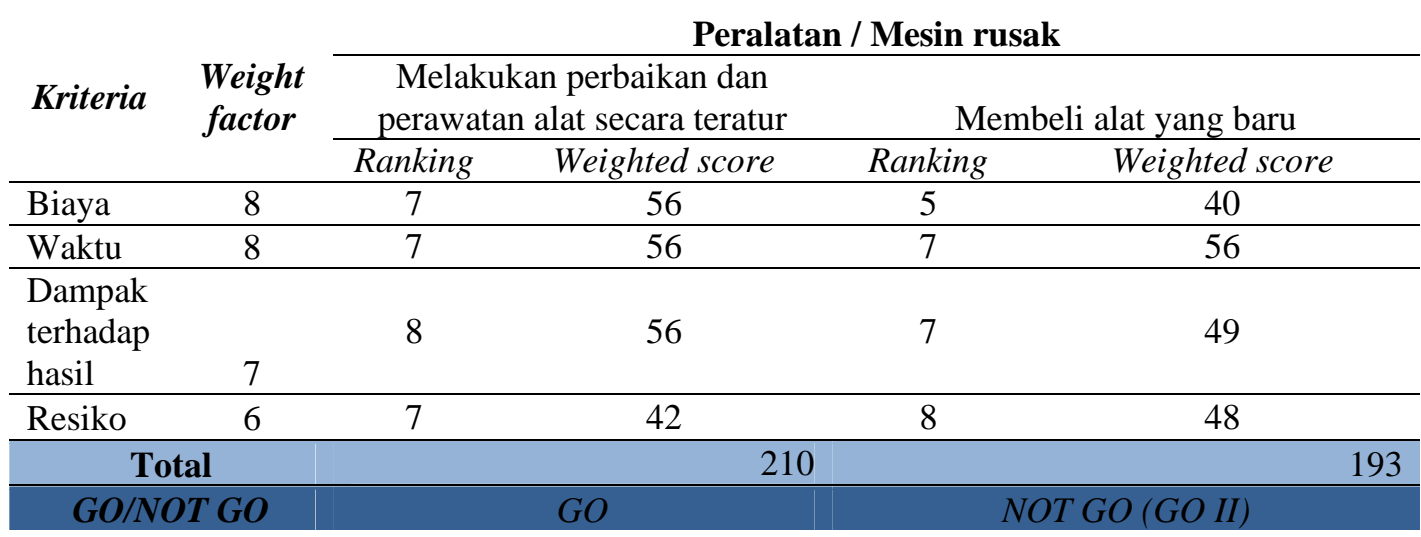

Setelah dilakukan evalusasi, di dapatkan solusi terbaik dari penyebab "cuaca buruk" adalah mengajukan surat pengajuan keterlambatan pekerjaan disertai dengan bukti-bukti dokumentasi sedangkan untuk penyebab alat atau mesin rusak dengan melakukan perbaikan dan perawatan alat secara teratur.

\section{c. Analisa Waste}

Dari hasil wawancara, didapatkan wasste paling berpontensi adalah waiting dan difect. Berikut ini tabel rekomendasi tindakan yang sebaiknya di lakukan oleh pihak pelaksana setelah adanya matriks evaluasi yang sesuai dengan identifikasi yang menggunakan formuasi if then yang di lakukan sebelumnya. 
Harliwanti Prisilia \& Dimas Aji Purnomo : Aplikasi Metode Lean Project Management

Dalam Perencanaan Proyek Konstruksi Pada Pembangunan Gedung SMU

Negeri 1 Giri Kabupaten Banyuwangi

Tabel 6. Rekomendasi Solusi Penyebab Waste setelah Evaluasi

\begin{tabular}{|c|c|c|}
\hline \multicolumn{3}{|c|}{ CONTROLING WASTE } \\
\hline If & Then & When \\
\hline \multirow{2}{*}{$\begin{array}{l}\text { Keterlambatan } \\
\text { Material }\end{array}$} & \multirow{2}{*}{$\begin{array}{l}\text { Melakuakan pekerjaan lainnya yang tidak } \\
\text { menggunakan material yang datang terlambat }\end{array}$} & Saat Pelaksanaan \\
\hline & & Saat Pelaksanaan \\
\hline \multirow{2}{*}{$\begin{array}{c}\text { Keterlambatan } \\
\text { penurunan dana }\end{array}$} & \multirow{2}{*}{ Menggunakan dana talangan } & Saat Pelaksanaan \\
\hline & & Saat Pelaksanaan \\
\hline \multirow[b]{2}{*}{ Cuaca buruk } & Mengajukan surat keterlambatan pengerjaan & Saat Pelaksanaan \\
\hline & $\begin{array}{l}\text { Melakukan percepatan pekerjaan saat cuaca } \\
\text { kembali normal }\end{array}$ & Saat Pelaksanaan \\
\hline \multirow{2}{*}{ Alat sering rusak } & $\begin{array}{l}\text { Melakukan perbaikan dan perawatan alat } \\
\text { secara teratur }\end{array}$ & Saat Pelaksanaan \\
\hline & Membeli alat yang baru & Saat Pelaksanaan \\
\hline
\end{tabular}

\section{d. Identifikasi dan Analisa Resiko \\ 1). Identifikasi Resiko}

Berdasrkan hasil wawancara didapatkan daftar kejadian yang tidak diharapkan yang berpotensi terjadi pada proyek pembangunan SMUN 1 Giri Banyuwangi yang dapat dilihat pada tabel berikut ini:

Tabel 7. Identifikasi risiko

\begin{tabular}{ll|l} 
Konsep & Sumber & Indikator
\end{tabular}

Eksternal tidak

dapat diprediksi

Acts of God dan natural hazard

\begin{tabular}{|c|c|}
\hline $\begin{array}{c}\text { Eksternal dapat } \\
\text { diprediksi }\end{array}$ & $\begin{array}{l}\text { Masalah dalam penyediaan sumberdaya (material; } \\
\text { tenaga kerj; alat) }\end{array}$ \\
\hline & Kondisi keuangan proyek yang buruk \\
\hline & Kondisi waktu pelaksanaan proyek yang buruk \\
\hline & K3 \\
\hline & Pencurian; kelalaian; Ketidakjujuran \\
\hline
\end{tabular}

Kerusakan alat; Properti; Fisik proyek

Dari tabel di atas kemudian di lakukan risk priority number yang disesuaikan dengan hassil wawancara pada manajer proyek. Berikut ini form penilaian resiko pada proyek pembanguna SMUN 1 Giri Banyuwangi. Pada tabel form penilaian resiko dilakukan Failure Mode and effectd Analysis (FMEA). Adapun rumus yang menentukan FMEA adalah: FMEA $=$ Kemungkinan $\mathrm{x}$ Dampak $\mathrm{x}$ Kesulitan Defeksi 
Tabel 8. Form penilaian risiko

\begin{tabular}{|c|c|c|c|c|c|}
\hline Indikator (peristiwa) resiko & Kemungkinan & Dampak & $\begin{array}{c}\text { Deteksi } \\
\text { Kesulitan }\end{array}$ & PMEA & Kapan \\
\hline $\begin{array}{c}\text { Acts of God dan natural } \\
\text { hazard }\end{array}$ & 2 & 5 & 5 & 50 & setiap saat \\
\hline $\begin{array}{l}\text { Masalah dalam penyediaan } \\
\text { sumberdaya (material; tenaga } \\
\text { kerja; alat) }\end{array}$ & 3 & 4 & 2 & 24 & $\begin{array}{c}\text { Sebelum } \\
\text { dan saat } \\
\text { pelaksanaan }\end{array}$ \\
\hline $\begin{array}{c}\text { Kondisi keuangan proyek } \\
\text { yang buruk }\end{array}$ & 2 & 4 & 2 & 16 & $\begin{array}{c}\text { Sebelum } \\
\text { dan saat } \\
\text { pelaksanaan }\end{array}$ \\
\hline $\begin{array}{l}\text { Kondisi waktu pelaksanaan } \\
\text { proyek yang buruk }\end{array}$ & 2 & 4 & 3 & 24 & $\begin{array}{c}\text { Saat } \\
\text { Pelaksanaan }\end{array}$ \\
\hline $\begin{array}{lll} \\
\end{array}$ & 1 & 4 & 4 & 16 & $\begin{array}{c}\text { Saat } \\
\text { Pelaksanaan }\end{array}$ \\
\hline $\begin{array}{l}\text { Pencurian; kelalaian; } \\
\text { Ketidakjujuran }\end{array}$ & 3 & 4 & 3 & 36 & setiap saat \\
\hline $\begin{array}{l}\text { Kerusakan alat; Properti; } \\
\text { Fisik proyek }\end{array}$ & 1 & 4 & 2 & 8 & $\begin{array}{c}\text { Saat } \\
\text { Pelaksanaan }\end{array}$ \\
\hline
\end{tabular}

Semakin tinggi nilai FMEA maka pihak pelaksana proyek harus meningkatkan kewaspadaan terhadap peristiwa resiko tersebut.

\section{2) Analisa Resiko}

Jika peristiwa resiko telah dikenali dan di beri nilai maka langka berikutnya adalah membuat keputusan untuk merespon dengan tepat peristiwa tersebut. Selain merespon setiap peristiwa resiko, juga perlu perencanaan kontingensi yang akan digunakan sebagai sebuah rencana alternatif jika suatu peristiwa resiko yang diperkirakan belom terjadi atau bahkan telah terjadi. Untuk mengetahui apatindakan yang perlu dilakukan dan bagaimana dapat mengatur peristiwa resiko yang telah diidentifikasi sebelumnya maka dapat digunakan matriks respon resiko seperti tabel berikut ini:

Tabel 9. Matriks respon risiko

\begin{tabular}{llll}
$\begin{array}{l}\text { Indikator (Peristiwa) } \\
\text { Risiko }\end{array}$ & Kemungkinan & Rencana Kontingensi & \multicolumn{1}{c}{ Pemicu } \\
\hline $\begin{array}{l}\text { Acts of God } \text { dan } \\
\text { natural hazard }\end{array}$ & Mengurangi & $\begin{array}{l}\text { Mengajukan surat } \\
\text { keterlambatan } \\
\text { pengerjaan }\end{array}$ & $\begin{array}{l}\text { Cuaca buruk } \\
\text { (tidak menentu) }\end{array}$ \\
\hline $\begin{array}{l}\text { Masalah dalam } \\
\text { penyediaan } \\
\text { sumberdaya (material; } \\
\text { tenaga kerj; alat) }\end{array}$ & Penghindaran & $\begin{array}{l}\text { Melakukan Analisa } \\
\text { Kebutuhan Sumber } \\
\text { Daya (material, tenaga } \\
\text { kerja, alat) sebelum } \\
\text { Pelaksanaan }\end{array}$ & $\begin{array}{l}\text { Kurang persiapan } \\
\text { dari pihak } \\
\text { pelaksana proyek }\end{array}$ \\
\hline $\begin{array}{l}\text { Kondisi keuangan } \\
\text { proyek yang buruk }\end{array}$ & Penghindaran & $\begin{array}{l}\text { Melakukan } \\
\text { Menganalisa kebutuhan } \\
\text { biaya proyek dengan } \\
\text { menyertakan dana } \\
\text { kontingensi / memakai }\end{array}$ & $\begin{array}{l}\text { Penurunan biaya } \\
\text { proyek terlambat } \\
\text { jidak sesuai }\end{array}$ \\
& & jadwal
\end{tabular}


Harliwanti Prisilia \& Dimas Aji Purnomo : Aplikasi Metode Lean Project Management Dalam Perencanaan Proyek Konstruksi Pada Pembangunan Gedung SMU Negeri 1 Giri Kabupaten Banyuwangi

dana talangan

\begin{tabular}{llll}
\hline $\begin{array}{l}\text { Kondisi waktu } \\
\text { pelaksanaan proyek } \\
\text { yang buruk }\end{array}$ & Penghindaran & $\begin{array}{l}\text { Membuat penjadwalan } \\
\text { dengan memberikan } \\
\text { buffer time }\end{array}$ & $\begin{array}{l}\text { Kurang persiapan } \\
\text { dari pihak proyek } \\
\text { dan kesalahan } \\
\text { menganalisa } \\
\text { penjadwalan } \\
\text { proyek }\end{array}$ \\
\hline K3 & Asuransi & Asuransi & $\begin{array}{l}\text { Perlengkapan alat } \\
\text { K3 tidak sesuai } \\
\text { dengan } \\
\text { standarisasi }\end{array}$ \\
\hline $\begin{array}{l}\text { Pencurian; kelalaian; } \\
\text { Ketidakjujuran }\end{array}$ & Penghindaran & $\begin{array}{l}\text { Pengadaan staff } \\
\text { keamanan di lokasi } \\
\text { proyek khususnya di } \\
\text { area gudang material }\end{array}$ & $\begin{array}{l}\text { Lokasi proyek } \\
\text { tidak aman }\end{array}$ \\
\hline $\begin{array}{l}\text { Kerusakan alat; } \\
\text { Properti; Fisik proyek }\end{array}$ & Penghindaran & $\begin{array}{l}\text { Maintenance / } \\
\text { perawatan secara } \\
\text { teratur (sesuai jadwal) }\end{array}$ & $\begin{array}{l}\text { Adanya } \\
\text { pengerjaan } \\
\text { proyek yang } \\
\text { tidak sesuai } \\
\text { prosedur }\end{array}$ \\
\hline
\end{tabular}
e. Managing variation dan penjadwalan CCPM
Variasi di dalam proyek diartikan ketidakpastian, untuk itu pihak pelaksana perlu memanage variasi,yang dilakukan dengan cara melakukan estimasi sebelum pelaksanaan proyek baik dari segi biaya, dan waktu, sumber daya yang digunakan. Langkah pertama yang dilakukan adalah mengestimasi biaya

proyek dari kebutuhan material dan tenaga kerja (sebelum PPN 10\% dan dana kontingensi), agar pihak pelaksana dapat memperkirakan total biaya proyek sesuai dengan nilai proyek yang sudah ditentukan pihak pemilik proyek atau justru melebihi. Estimasi biaya dilakukan dengan merinci kebutuhan material dari tiap jenis pekerjaan.

Tabel 10. Rincian Total Biaya Proyek

\begin{tabular}{clrr} 
No & \multicolumn{1}{c}{ Uraian Pekerjaan } & $\begin{array}{c}\text { Jumlah } \\
(\mathbf{R p})\end{array}$ & \multicolumn{1}{c}{$\begin{array}{c}\text { Total } \\
\text { Bobot }\end{array}$} \\
\hline 1 & Pekerjaan Persiapan & $30.981 .730,000$ & 0,85 \\
\hline 2 & Pekerjaan Tanah Dan Urugan & $85.926 .500,280$ & 2,36 \\
\hline 3 & Pekerjaan Pasangan Pondasi & $24.912 .836,160$ & 0,68 \\
\hline 4 & Pekerjaan Beton Pondasi \& Kolom & $898.460 .175,500$ & 24,68 \\
\hline 5 & Pekerjaan Struktur Lantai Dua & $791.774 .116,600$ & 21,75 \\
\hline 6 & Pekerjaan Struktur Lantai Tiga & $770.320 .033,600$ & 21,16 \\
\hline 7 & Pekerjaan Struktur Beton Atap & $385.547 .295,500$ & 10,59 \\
\hline 8 & Pekerjaan Pasangan Dinding & $58.925 .852,000$ & 1,62 \\
\hline 9 & Pekerjaan Beton & $78.955 .080,480$ & 2,17 \\
\hline 10 & Pekerjaan Plesteran & $85.240 .964,800$ & 2,34 \\
\hline 11 & Pekerjaan Kusen, Pintu, \& Jendela & $125.979 .493,500$ & 3,46
\end{tabular}


Harliwanti Prisilia \& Dimas Aji Purnomo : Aplikasi Metode Lean Project Management Dalam Perencanaan Proyek Konstruksi Pada Pembangunan Gedung SMU Negeri 1 Giri Kabupaten Banyuwangi

\begin{tabular}{rlrr}
12 & Pekerjaan Plafon & $83.083 .410,66$ & 2,28 \\
\hline 13 & Pekerjaan Pengecetan & $37.453 .907,800$ & 1,03 \\
\hline 14 & Pekerjaan Pasangan Keramik & $109.395 .169,200$ & 3,01 \\
\hline 15 & Pekerjaan Instalasi Listrik & $23.365 .320,000$ & 0,64 \\
\hline 16 & Pekerjaan Instalasi Air & $45.903 .730,000$ & 1,26 \\
\hline 17 & Pekerjaan Penggantung \& Asessoris & $12.948 .740,000$ & 0,36 \\
\hline 18 & Pekerjaan Tambahan & $54.958 .310,28$ & 1,51 \\
\hline & Jumlah total & $\mathbf{3 . 6 3 9 . 8 6 6 . 4 7 7 , 2 2}$ & $100 \%$
\end{tabular}

Dari rincian biaya di atas didapatkan total biaya proyek (sebelum PPN 10\% dan dana kontingensi) sebesar Rp. 3.639.866.477,22 total biaya setelah PPN yaitu sebesar Rp. 4.003.853.000,00. Sedangkan nilai dari proyek yang akan di kerjakan sebesar Rp. 4.014.000.000,00. Hal ini berarti biaya proyek dapat di terima karena tidak melampaui nilai proyek yang telah di tetapkan oleh pihak pemilik proyek.

Setelah melakukan estimasi biaya, kemudian melakukan estimasi penjadwalan dengan meggunakan kurva $\mathrm{S}$ dan critical chain Project Management. Dari hasil pembobotan kurva S didapatkan bahwa pekerjaan yang memiliki bobot yang paling besar yaitu pekerjaan Plat Dack Lantai tiga yaitu sebesar 11,59. Hal ini berarti pekerjaan Plat Dack Lantai tiga merupakan kegiatan yang paling rumit jika dilihat dari sisi biaya. Namun berdasarkan akumulasi pembobotan pekerjaan dari sisi waktu, yang memiliki bobot paling tinggi yaitu pada minggu ke 5 sampai minggu ke 7 yaitu dengan bobot 3,53 yaitu untuk pekerjaan struktur lantai dua balok T2.

Kemudian pada proses penjadwalan CCPM, sebelum dilakukan, dapat dilihat jadwal existing dari proyek pembangunan gedung SMUN 1 Giri Banyuwangi. Berikut adalah rencana penjadwalan eksisting proyek dalam tabel 11.

Tabel 11. Rencana Penjadwalan Existing

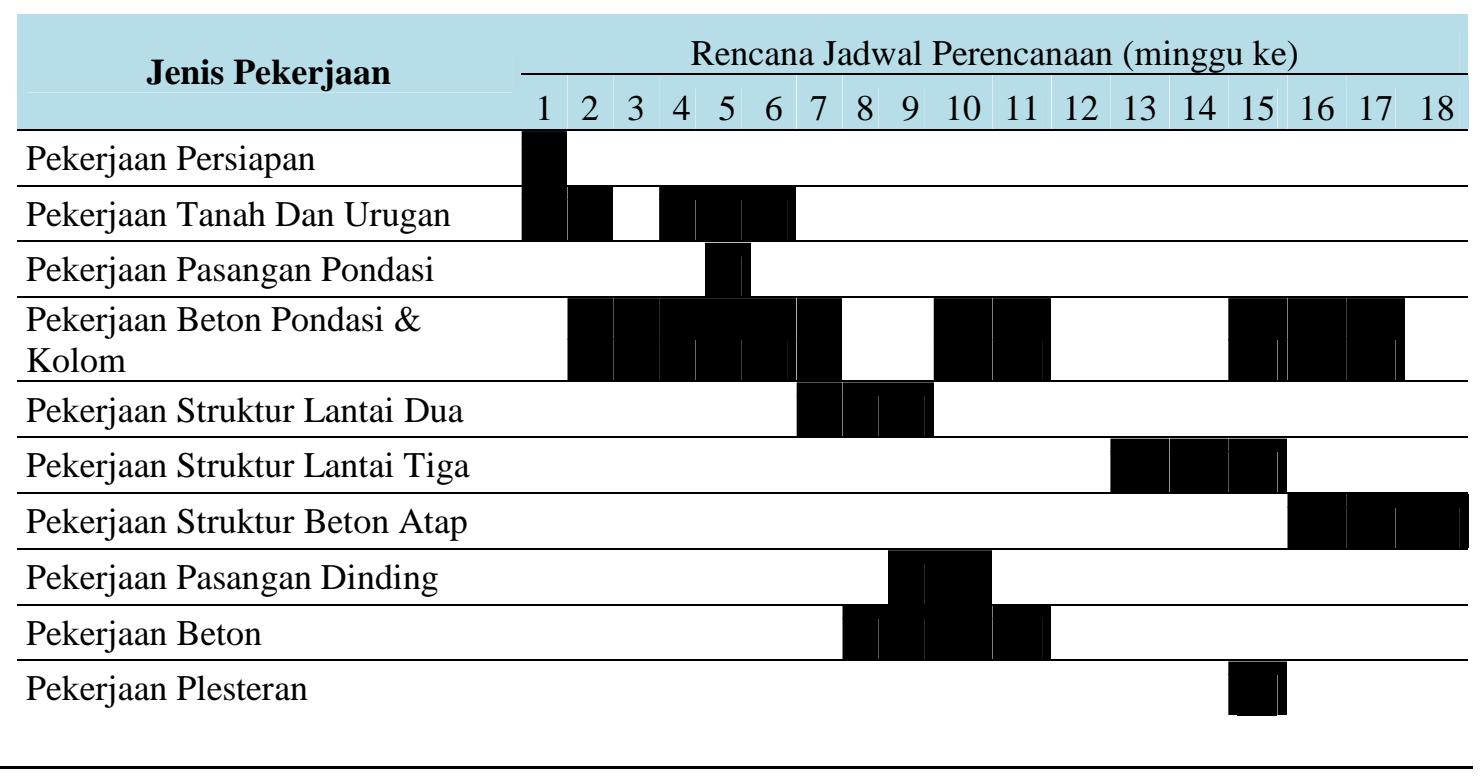


Harliwanti Prisilia \& Dimas Aji Purnomo : Aplikasi Metode Lean Project Management Dalam Perencanaan Proyek Konstruksi Pada Pembangunan Gedung SMU Negeri 1 Giri Kabupaten Banyuwangi

Pekerjaan Kusen, Pintu, \& Jendela

\begin{tabular}{ll|l|l|}
\hline Pekerjaan Plafon & \\
\hline Pekerjaan Pengecetan & \\
\hline Pekerjaan Pasangan Keramik & \\
\hline Pekerjaan Instalasi Listrik & & & \\
\hline Pekerjaan Instalasi Air & & & \\
\hline Pekerjaan Penggantung \& \\
Asessoris
\end{tabular}

Di dalam CCPM terdapat buffer time yaitu waktu penyangga, yang digunakan untuk melindungi ketidakpastian yang berpotensi menimbulkan keterlambatan target penyelesaian proyek. Dari hasil identifikssi penjadwalan didapatkan bahwa aktivitas kritis pada proyek ini adalah Plat dack Lantai Tiga, $\mathrm{t}-12 \mathrm{~cm}$, beton K-225/ready mix, $110 \mathrm{~kg}$ besi polosdan project buffer, untuk itu perlu dialokasikan feeding buffer sebelum Plat dack Lantai Tiga, t-12 cm, beton K-225/ready mix, $110 \mathrm{~kg}$ besi polosdan project buffer,dengan tujuan agar variasi dari pekerjaan tersebut menggangu aktivitas kritis. Pada tabel 5.7 berikut ini dapat dilihat perhitungan alokasi feeding buffer untuk pekerjaan Plat dack Lantai Tiga, t-12 cm, beton K225/ready mix, $110 \mathrm{~kg}$ besi polos dan project buffer.

Tabel 12. Perhitungan Project Buffer

\begin{tabular}{|c|c|c|c|c|}
\hline Jenis Pekerjaan & $\begin{array}{l}\text { Waktu } \\
\text { Tercepat } \\
\text { (A) }\end{array}$ & $\begin{array}{c}\text { Waktu yang } \\
\text { masih } \\
\text { menyimpan } \\
\text { waktu } \\
\text { cadangan (S) }\end{array}$ & $(\mathrm{S}-\mathrm{A}) / 2$ & $\begin{array}{c}(\mathrm{S}-\mathrm{A}) / 2 \mathrm{x} \\
(\mathrm{S}-\mathrm{A}) / 2\end{array}$ \\
\hline PEKERJAAN PERSIAPAN & 6 & 6 & 0 & 0 \\
\hline PEKERJAAN TANAH \& URUGAN & 57 & 58 & 0.5 & 0.25 \\
\hline $\begin{array}{l}\text { PEKERJAAN PASANGAN } \\
\text { PONDASI }\end{array}$ & 4 & 5 & 0.5 & 0.25 \\
\hline $\begin{array}{l}\text { PEKERJAAN BETON PONDASI \& } \\
\text { KOLOM }\end{array}$ & 112 & 112 & 0 & 0 \\
\hline $\begin{array}{l}\text { PEKERJAAN STRUKTUR LANTAI } \\
\text { DUA }\end{array}$ & 26 & 26 & 0 & 0 \\
\hline $\begin{array}{l}\text { PEKERJAAN STRUKTUR LANTAI } \\
\text { TIGA }\end{array}$ & 23 & 25 & 1 & 1 \\
\hline $\begin{array}{l}\text { PEKERJAAN STRUKTUR BETON } \\
\text { ATAP }\end{array}$ & 18 & 18 & 0 & 0 \\
\hline $\begin{array}{l}\text { PEKERJAAN PASANGAN } \\
\text { DINDING }\end{array}$ & 11 & 13 & 1 & 1 \\
\hline PEKERJAAN BETON & 18 & 18 & 0 & 0 \\
\hline PEKERJAAN PLESTERAN & 13 & 13 & 0 & 0 \\
\hline $\begin{array}{l}\text { PEKERJAAN KUSEN, PINTU \& } \\
\text { JENDELA }\end{array}$ & 19 & 19 & 0 & 0 \\
\hline PEKERJAAN PLAFOND & 23 & 23 & 0 & 0 \\
\hline PEKERJAAN PENGECATAN & 4 & 5 & 0.5 & 0.25 \\
\hline
\end{tabular}


Harliwanti Prisilia \& Dimas Aji Purnomo : Aplikasi Metode Lean Project Management Dalam Perencanaan Proyek Konstruksi Pada Pembangunan Gedung SMU Negeri 1 Giri Kabupaten Banyuwangi

\begin{tabular}{lllll} 
PEKERJAAN PASANGAN KRAMIK & 27 & 27 & 0 & 0 \\
\hline PEKERJAAN INSTALASI LISTRIK & 30 & 30 & 0 & 0 \\
\hline PEKERJAAN INSTALASI AIR & 56 & 58 & 1 & 1 \\
\hline $\begin{array}{l}\text { PEKERJAAN PENGGANTUNG \& } \\
\text { ASESORIS }\end{array}$ & 12 & 14 & 1 & 1 \\
\hline PEKERJAAN TAMBAHAN & 43 & 43 & 0 & 0 \\
\hline
\end{tabular}

Dengan sesuai penjadwalan CCPM, panjang durasi yang di butuhkan untuk penyelesaikan proyek pembangunan gedung SMUN 1 Giri Banyuwangi hanya 131 hari (termasuk buffer time) dan jauh lebih singkat dibandingkan dengan jadwal eksisting yang membutuhkan waktu lebih lama yaitu sepanjang 160 hari. Dengan mengetahui jadwal proyek tersebut, pihak pelaksanadapat melaksanakan estimasi kepada tenaga kerja pada setiap pekerjaan.

\section{KESIMPULAN}

1. Hasil identifikasi waste dilakukan berdasarkan waste yang berpengaruh dan berpotensi pada proyek yang digunakan. Sebagai obyek pengamatan dari hasil wawancara dari pihak pelaksana menurut 8 waste yang telah didenifisikan oleh Womack and Jones 1996 adalah waiting dan difect. Waste waiting di sebabkan karena faktor keterlambatan material, keterlambatan penurunan dana, cuaca buruk dan alat/ mesin yang sering rusak. Sedangkan waste difect disebabkan karena cuaca buruk dan alat/mesin yang sering rusak.

2. Hasil penilaian resiko menurut hasil perhitungan FMEA,diketahui nilai terbesar dengan nilai 50 yaitu masalah Acts of God and Natural Hazard, dimana resiko tersebut sulit untuk diprediksi seperti banjir, hujan dan bencana alam

3. Hasil penjadawalan dengan CCPM didapatkan waktu mengerjakan proyek adalah 131 hari dimana lebih cepat 29 hari dibandingkan dengan menggunakan penjadwalan eksisting selama 160 hari, dengan estimasi biaya proyek sebesar (sebelum PPN 10\% dan dana kontingensi) sebesar Rp. 3.639.866.477,22 juta, total biaya setelah PPN yaitu sebesar Rp. 4.003.853.000,00. Sedangkan nilai dari proyek yang akan di kerjakan sebeesar Rp. 4.014.000.000,00. Hal ini berarti biaya proyek dapat di terima karena tidak melampaui nilai proyek yang telah di tetapkan oleh pihak pemilik proyek.

4. Biaya penghematan tenaga kerja dengan penjadwalan CCPM perharinya adalah Rp 3.291.212,53 sehingga Untuk penjadwalan dengam menggunakan metode CCPM lebih singkat 29 hari, maka total penghematan biaya di peroleh sebesar Rp. 95. 445. 163,49. Sedangkan dana kotingensi untuk cadangan anggaran dan cadangan manajement total adalah sebesar Rp. 1.201.155.900,00.

\section{SARAN}

1. Saran yang dapat dijadikan untuk penelitian ini adalah agar pihak pelaksana dapat mengimplementasikan Lean 
Harliwanti Prisilia \& Dimas Aji Purnomo : Aplikasi Metode Lean Project Management Dalam Perencanaan Proyek Konstruksi Pada Pembangunan Gedung SMU Negeri 1 Giri Kabupaten Banyuwangi

$\begin{array}{lr}\begin{array}{l}\text { Project Management pada } \\ \text { proyek-proyek }\end{array} & \text { selanjutnya } \\ \text { untuk mengantisipasi } & \text { meterlambatan proyek. }\end{array}$

Project Management pada untuk mengantisipasi keterlambatan proyek.
2. Pihak pelaksana proyek agar lebih memperhatikan unsur keselamatan pekerja dalam pelaksanaan poyek.

\section{DAFTAR PUSTAKA}

Anggraeni, Nyoman. 2009. Penerapan Metode Penjadwalan Critical Chain dan Lean Constructiondalam Perencanaan dan Pengendalian Proyek Konstruksi (Studi Kasus : PT. Adhi Karya(Persero), Tbk), Tugas Akhir. Jurusan Teknik Industri ITS, Surabaya.

Archia, Itqan., dan Singgih, Moses L. 2013. Penerapan Metode Lean Construction dan Penjadwalan Critical Chain Project Management Dalam Pembangunan Proyek Konstruksi Gedung Universitas Widya Mandala (UWM) Surabaya (Studi Kasus : PT.PP (Persero). Tbk). Skripsi. Institut Teknologi Sepuluh Nopember. Surabaya.

Artika, Dian. 2014. Penerapan Metode Lean Project Management Dalam Proyek Konstruksi Pada Pembangunan Gedung DPRD Kabupaten Ogan Ilir. Jurnal Teknik Sipil dan Lingkungan. Vol. 2, No 1, Maret 2014.

Aulady, Mohamad., dan Orleans, Cesaltino. 2016. Perbandingan Durasi Waktu Proyek Konstruksi Antara Metode Critical Path Method (CPM) dengan Metode Critical Chain Project Management (Studi Kasus : Proyek Pembangunan Apartemen Menara Rungkut ). Jurnal IPTEK. Vol. 20 No1, Mei 2016.

Busyral, Muhammad. 2012. Perencanaan dan Pengendalian Proyek Konstruksi Menggunakan Critical Chain Project Management dan Lean Construction Untuk Meminimasi Waste (Studi Kasus : Pembangunan Gedung Bppkb Tahap 2). Tugas Akhir. Jurusan Teknik Industri ITS, Surabaya.

Ghaffari, Mahdi., and Emsley, Margaret, W. 2015. Current Status and Future Potential of the research on Critical Chain Project Management. PM World Journal. Volume IV Issue IX - September 2015.

Gray, C. and Larson, E. 2006. The ManagerialProcess 3th Edition. McGraw-Hill Company,New York.

Hapsari, Ratih Indri. 2011. Penerapan Metode Lean Project Management dalam Perencanaan Proyek Konstruksi pada Pembangunan Gedung SDN Bektiharjo II Semanding Tuban. Tugas Akhir. Jurusan Teknik Industri Institut Teknologi Sepuluh Nopember (ITS) Surabaya.

Husen, A.2009. Manajemen Proyek. CV Andi Offsett. Yogyakarta.

Ismael, I., dan Junaidi. (2014, Februari). Identifikasi Faktor-Faktor Yang Mempengaruhi Keterlambatan Pelaksanaan Pekerjaan Pada Proyek Pembangunan Gedung Di Kota Bukittinggi. Jurnal Momentum, Vol.16, 25-36.

Leach, L. P. 2005. Lean ProjectManagement:Eight Principles for Success.Artech House, Norwood.

Nurlela dan Suprapto, Heri. 2014. Identifikasi dan Analisis Manajemen Risiko Pada Proyek Pembangunan Infrastruktur bangunan Gedung Bertingkat. Jurnal Desain Konstruksi. Volume 13 No2, Desember 2014.

Santosa, Budi. 2013. Manajemen Proyek Konsep dan Implementasi. Graha Ilmu, Yogyakarta.

Untu, Silvia.,dkk. 2014. Penerapan Metode Lean Project Management dalam perencanaan proyek konstruksi (studi kasus : Pembangunan Gedung Mantosh Tahap III), Jurnal Sipil statik vol.2 No. 6, September 2014 (320-329) ISSN:23376732 .

Womack, J. and Jones, D.1996. Lean Thinking: Banish Waste And Create Wealth in Your Corporation. Simonand Schus, NewYork 